\title{
Role of Exogenous Salicylic Acid and Benzoic Acid Applications to Vascular Streak Dieback Disease Attack on Cocoa Seedlings
}

\author{
Fakhrusy Zakariyya $^{\left.1^{*}\right)}$, Agung Wahyu Susilo ${ }^{1)}$, Teguh Iman Santoso ${ }^{1)}$, Hardian Susilo Addy ${ }^{2}$, \\ and Sulistyani Pancaningtyas ${ }^{1)}$
${ }^{1}$ Indonesian Coffee and Cocoa Research Institute, Jl. PB. Sudirman 90, Jember, Imdonesia
${ }^{2}$ Faculty of Agriculture, University of Jember, Jl. Kalimantan, Tegaboto, Jember, Indonesia Corresponding author: fakhruzy.zakariyya@gmail.com Received: 25 October 2017 / Accepted: 19 January 2018

\begin{abstract}
Currently, vascular streak dieback (VSD) attacks have widespread in areas of the center of cocoa (Theobroma cacao L.) production, especially in Sulawesi. Salicylic acid and benzoic acid are part of phenol compounds reportedly acts as bioimmunoregulator in increasing of plant resistance to that pathogen. The objective of this research was to investigate effect of exogenous salicylic acid and benzoic acid applications to VSD disease attack on cocoa seedlings. The research was conducted at Indonesian Coffee and Cocoa Research Institute, Jember, East Java. This experiment designed using randomized completely block design with three replications. The treatments included concentrations of salicylic acid in 0.5 mMol, $1 \mathrm{mMol}, 2 \mathrm{mMol}$; benzoic acid with concentration $0.5 \mathrm{mMol}, 1 \mathrm{mMol}, 2 \mathrm{mMol}$; and control (water spray). Observations were based on the incidence and severity damage of disease, plant height, stem diameter, number of leaves, stelate trichome, chlorophyll, width and length of stomatal apperture, and number of stomata. Exogenous salicylic acid and benzoic acid as phytohormone can reduce disease insidence and severity of VSD. In conclusion, our results indicated that exogenous salicylic acid and benzoic promoted stomatal closure in cocoa leaf by decreasing width-stomatal closure. Salicylic and benzoic acid had no effect to plant height, stem diameter, number of leaves, length of stomatal apperture, number of stomata, and number of stelate trichome.
\end{abstract}

Keyword: Theobroma cacao L., salicylic acid, benzoic acid, vascular streak dieback, incidence, severity

\section{INTRODUCTION}

Indonesia is the third largest cocoa producer in the world after Ivory Coast and Ghana with production volume up to 701.299 ton which contributing $18,4 \%$ in world cocoa production (Ditjenbun, 2015). Among the main obstacles in cocoa cultivation, there are attacks of vascular-streak dieback (VSD) disease that causes yield loss up to $60 \%$ (Sukamto \& Junianto, 1986). Currently, the VSD attacks have widespread in areas that decreasing the center of cocoa production, especially Sulawesi, with estimation total area in infected by VSD reached 951.823 ha over ten provinces (Ditjenbun, 2014). Some solutions to overcome VSD attack have been made through the application of the resistant planting materials and cultural control treatment. Utilization of resistant planting materials is effectively proven, but its application needs high infestation costs and need a long time. Therefore, it is part of a long-term control strategy. Treatment of cultural control is a short-term strategy, but this solution is often less-effective and 
relatively need high cost. To improve the effectiveness of VSD control technology, it is necessary to look for a technique that effective and efficient to control VSD that can be applied in short-term control, especially to overcome VSD attacks on existing cocoa plants.

The extent damage of plant due to VSD attacks is majorly determined by the level of plant resistance (Sukamto, 2008), thus, the effective controlling technique is through plant resistant genetic. It can be from plant breeding or induction plant resistance. Inducing of plant resistance is an alternative control technique that can be applied through application of induced material from outside of the plant to overcome the VSD attacks problem on existing cocoa plants. Some reports mentioned the presence of exogeneous hormone addition, which salicylic acid and benzoic acid that can regulate plant resistance to pathogens. Salicylic acid (SA) and benzoic acid (BA) are part of phenol compounds reportedly acts as bioimmunoregulator in increasing of plant resistance to the pathogen, especially fungi. Several studies have reported that salicylic acid effectively suppresses the growth of Phytopthora plamivora and Monilopthora perniciosa in cocoa (Kilaru et al., 2007; Harni et al., 2013).

Salicylic acid and benzoic acid occur naturally in plants in very low amounts, which regulating various physiological processes. Exogenous application of SA and BC play a critical role in stomatal closure, nutrient uptake, chlorophyll synthesis, protein synthesis, photosynthesis, ethylene synthesis (Kabiri et al., 2014; Khandaker et al., 2011; Amin et al., 2016), and phenolic metabolism that are important in the defence against pathogen in plants (Misra et al., 2014). The mechanism of these two hormones in resistance of cocoa plant is suspected by physiological and anatomical processes by supporting plant growth in marginal environ- ment especially when the condition is attacked by VSD. The objective of this research was to investigate effect of exogenous SA and BA applications to VSD disease attack on cocoa seedlings.

\section{MATERIALS AND METHODS}

The research was conducted at Indonesian Coffee and Cocoa Research Institute (ICCRI), Jember, East Java. The seedlings derived from the top grafting of ICS 60 clone which was susceptible to VSD. VSD inoculation based on natural occurrence infestation in VSD endemic areas, Kaliwining Experimental Station of ICCRI (45 m asl.). Inoculation was conducted during rainy season, and symptom would be performed in dry season.

This experiment was set using completely randomized design with there replications. The treatments included concentration of salicylic acid (SA) in $0.5 \mathrm{mMol} ; 1 \mathrm{mMol}$; $2 \mathrm{mMol}$; benzoic acid (BA) with concentration $0.5 \mathrm{mMol}, 1 \mathrm{mMol}, 2 \mathrm{mMol}$; and control (water spray). Treatments were applied through foliar spraying to young leaf with frequency once in every two weeks.

Evaluations were based on incidence and severity of VSD symptom, plant height, stem diameter, leaf number, stelate trichome, chlorophyll, width and length of stomatal apperture, and stomata number. Chlorophyll was measured with SPAD-meter (Minolta series 502, Japan). Trichome and stomatal traits observation included the length stomatal apperture, width stomatal apperture opening, and number of stomata which observed using nail polish. The observation was done microscopically, using binocular microscope at $40 \mathrm{x}$ magnification.

The incidence of disease was observed with the response of plant resistance against to VSD and evaluated based on damage score of the plant (Nur'aini, 2015). The extent of VSD 
attack was observed every month by calculating percentage of incidents that included in Oncobasidium theobromae symptom attack, which: 1) dried leaves and dead twigs, 2) yellowing leaves with green patches (usually that leaves located in second or third leaf from growing point), 3 ) in the petiole traces if it sliced will be seen 3 pieces of yellow spot colored blackish brown, 4) if the twigs slashed longitudinally will be seen brown line in xylem that leads to the petiole, 5) lenticels in infected twigs are enlarged and relative coarse, 6) leaves showed necrosis symptom between the midrib like the symptom deficiency of potassium.

The VSD attack criteria were made through disease incidence (DI) in the seedlings that measured by counting number of seedlings attacked by VSD (n) then divided with total of all seedlings that observed $(\mathrm{N})$ by the formula:

$$
\text { Incidence }=\frac{\mathrm{n}}{\mathrm{N}} \times 100 \%
$$

Disease severity was observed by using scoring technique calculated using formula below:

$$
\begin{aligned}
& \text { Severity }=\frac{\sum_{i=1}^{n}(n \cdot v)}{z \cdot n} \times 100 \% \\
\text { DI }= & \text { Disease Incidence } \\
\mathrm{n} \quad= & \text { Number of plants with score } \mathrm{v} \\
\mathrm{v} \quad= & \text { score number-i } \\
\mathrm{z} \quad= & \text { highest score value }
\end{aligned}
$$

Assessment scores of VSD disease severity on cocoa seedling: 0 (healthy, $0 \%$ infected); 1 (very light, $<5 \%$ of the leaves are infected); 2 (light, $5-10 \%$ of leaves are infected, chlorosis and necrosis, no falling off leaves, there is swelling lenticel); 3 (medium, $10-25 \%$ of leaves are infected, chlorosis, necrosis, there is falling off leaves and swelling lenticels); 4 (quite severe, $25-50 \%$ of leaves are infected, chlorosis, necrosis, there is falling off leaves and swelling lenticels); 5 (severe, $50-75 \%$ of leaves are infected, chlorosis, necrosis, there is falling off leaf and swelling lenticels, there is stipe); and 6 (very severe, $>75 \%$ of leaves are infected, chlorosis, necrosis, there is falling off leaf and swelling lenticels, there is stipe, twigs die).

Data were analyzed using ANOVA with SAS software. If there is a significant difference, it will be continued with post hoc test Duncan multiple range test (DMRT) at $\alpha=5 \%$ level. For the analysis diseases incidence and severity data, it differentiated between control and treatments, then analyzed using post hoc test DMRT at $\alpha=5 \%$ level.

\section{RESULTS AND DISCUSSION}

Salicylic and benzoic acid are important phytohormones that regulate various aspect in plant growth and development, especially in resistance against to abiotic and biotic stress. Figure 1 showed that exogenous addition of SA and BA can decrease the incidence and severity of VSD attacks in cocoa. Addition of SA in $0.5 \mathrm{mMol}$ showed $26.7 \%$ incidence degression and $11.11 \%$ degression of disease severity compared with control. The same thing was also shown by the addition of BA. Optimum addition of BA in $0.5 \mathrm{mMol}$ concentration showed that decreased disease incidence up to $13.30 \%$ and $5.56 \%$ in disease severity. But along with the increase of the salicylic and benzoic acid concentration, the incidence value of the cocoa seedlings that attacked by VSD was relatively similar with control, although at the severity it shown relatively smaller. These indicate that the SA and BA must be on optimal value of concentration.

Amborabe et al. (2002) demonstrated that SA and BA had an antifungal effect on Eutypa lata pathogen that attacked in xylem. A similar case reported by Yao \& Tian (2005), where the addition of SA on sweet cherry during the pre-harvest caused incidence degression by inhibiting the growth of 
Monolinia fructiola mycelium. Salicylic acid can induce beta-1,3-glucanase, phenylalanine ammonia-lyase (PAL) and peroxidase (POD) that involved in disease resistance (Yao \& Tian, 2005; Bartoncelli et al., 2016). The exogenous SA addition was reported by Maity et al. (2017) that it can increase phenolic compounds, the activity of antioxidant superoxide dismutase, peroxidase, and catalase. Vance et al. (1980) and Kuvalekar \& Gandhe (2010) stated if peroxidase was involved in the oxidation of polymerization of hydroxycinnamyl alcohols to yield lignin and cross linking isodityrosine bridges in cell wall. The formation of lignins and phenol was reported by Yuliasmara et al. (2011) that can increase the resistance of cocoa seedlings against to VSD attack. William et al. (2003) demonstrated application of BA $(0.10-0.50 \mathrm{mM})$ as a foliar spray or soil drench improved biotic stress tolerance to Phytopthora cinnamomi in Banksia attenuate plants.

The infection through stomata during the rainy season become one of the ways how VSD fungus infected. Most diseases by infectious agents begin when the pathogen contacts host plants. Therefore, some anatomical characteristics of leaves can act as physical barriers to pathogens penetrating a host plant, such as trichome, stomata, epidermis cell (Santoso, 2017). Susilo et al. (2016) stated that aperture and number of stomata can affect the infection of Oncobasidium theobromae in cocoa. The addition of SA and BA seem to contribute to the closure of stomatal gap that showed in Table 2. The stomatal-width aperture in SA and BA showed significant different compared with control treatment $(1,63 \mu \mathrm{m})$. Salicylic and BA gave effect on the stomatalwidth aperture respectively $58.9 \%$ and $20.7 \%$ tighter compared with control treatment. This was supported by the research that conducted by Sun et al. (2010) and Khokon et al. (2017) where the addition of SA plays a role in stomatal closure. Similiar case also reported by Faridudin et al. (2003) and Anjum et al. (2011) that BA affects on stomata that continued with gas exchange. Hao et al. (2011) explained that those hormones play a role in modulating endogenous hormone especially $\mathrm{ABA}$, so the use of it is for stomatal closure. Stomatal-length aperture and number of stomatal were not significantly different between the addition of SA, BA, and control.

At the number of stelate trichome showed there is no significant difference. War et al. (2013) demonstrated that exogenous SA did not affect on increasing of trichome, but

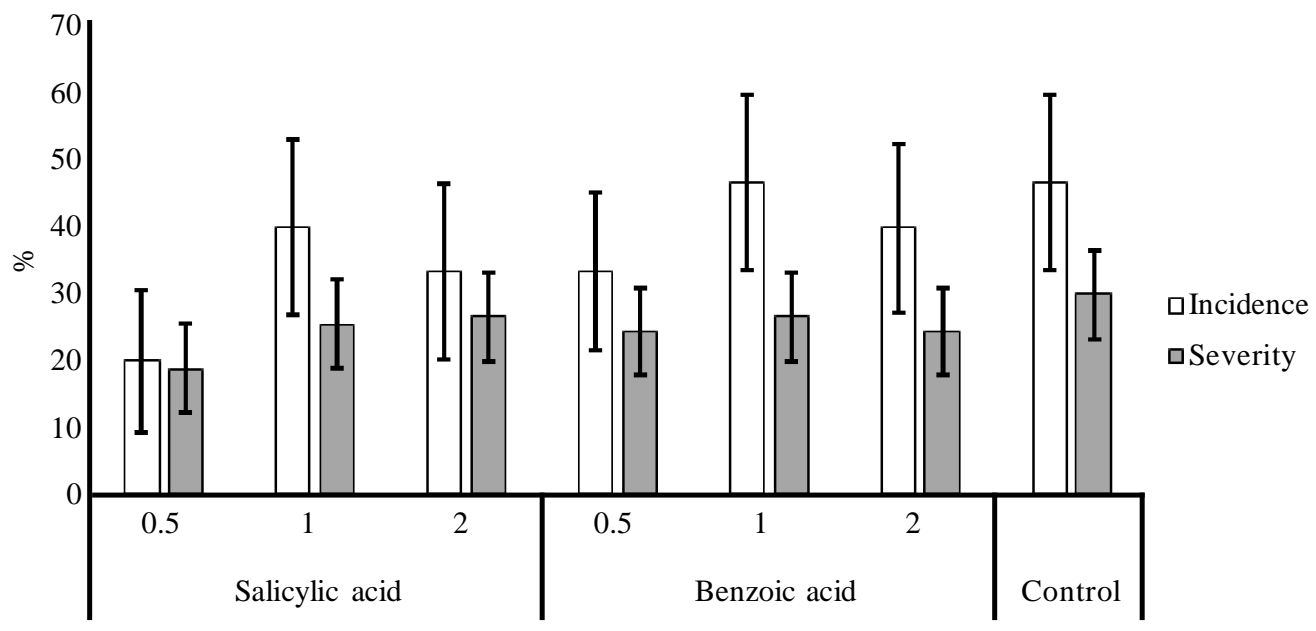

Figure 1. Disease incidence and severity as affected by salicylic and benzoic acid application (Mean \pm standard error) 
Traw \& Bergelson (2003) stated that SA has negative effect on trichome production. However, we did not find effect on exogenous SA and BA on cocoa seedlings in terms of trichome production. Trichomes are the most important structural features of plant defence against pathoghen infection (Santoso et al., 2017). These are hairy structures present on stem, leaves and fruits. They can be straight, spiral, stellate or hooked (Agrawal, 1999; Hanley et al. 2007).

Table 2 showed the growth of cocoa seedlings. Addition of SA and BA were not significantly different on plant height, stem diameter, number of leaf, but significantly different on plant chlorophyll. The value of chlorophyll on 0.5 and $2 \mathrm{BA}$ addition showed chlorophyll content increased $6.2 \%$ and $10.47 \%$ compared with control, respectively. While on $0.5 \mathrm{mMol}$ SA addition showed that the treatment can contribute to enhancement of chlorophyll content $8,88 \%$ and showed significantly different compared with control. Maity et al. (2016) showed that pomegranate that treated with SA will increase the chlorophyll content and also affects in plant total dry weight. Benzoic acid treatment is in agreement with Fariduddin et al. (2003) that $\mathrm{SA}$, which analogue of $\mathrm{BA}$, treatment enhanced the net photosynthetic rate, intercellular $\mathrm{CO}_{2}$, water use efûciency, stomatal conductance and transpiration rate in Brassica juncea. Stomatal conductance and transpiration rate increased with increase in photosynthetic rate due to BA treatment, which suggests that BA-induced increase in photosynthesis might have been due to stomatal factors. Similarly Amin et al. (2016) reported that BA at $5-20 \mathrm{mg} / \mathrm{L}$ stimulated the growth parameter with an elevated levels of growth promoters (IAA, GA, total cytokinin) chlorophyll increase.

\section{CONCLUSIONS}

Exogenous salicylic acid and benzoic acid as phytohormone can reduce disease insidence and severity of VSD. The best concentration of salicylic acid was $0.5 \mathrm{mMol}$ that potentially decrease VSD disease insidence and severity up to $26.7 \%$ and $11.11 \%$, respectively. Meanwhile, BA $0.5 \mathrm{mMol}$ could decrease incidence and severity up to $13.30 \%$ and $5.56 \%$,

Table 1. Effect of Salicylic acid anc benzoic acid on stomatal characters and number of stelate trichome

\begin{tabular}{|c|c|c|c|c|c|}
\hline \multirow{2}{*}{ Treatment } & \multirow{2}{*}{ Concentration } & \multicolumn{2}{|c|}{ Stomatal-aperture } & \multicolumn{2}{|c|}{ Number } \\
\hline & & Width, $\mu \mathrm{m}$ & Length, $\mu \mathrm{m}$ & Stomata & Stelate trichome \\
\hline \multirow[t]{3}{*}{ Benzoic acid } & $0.5 \mathrm{mMol}$ & $1.38 \mathrm{c}$ & $4.45 \mathrm{a}$ & $30.67 \mathrm{a}$ & $5.67 \mathrm{a}$ \\
\hline & $1 \mathrm{mMol}$ & $1.29 \mathrm{bc}$ & $4.35 \mathrm{a}$ & $39.00 \mathrm{a}$ & $7.67 \mathrm{a}$ \\
\hline & $2 \mathrm{mMol}$ & $1.21 \mathrm{bc}$ & $4.27 \mathrm{a}$ & $48.33 \mathrm{a}$ & $3.67 \mathrm{a}$ \\
\hline \multirow[t]{3}{*}{ Salicylic acid } & $0.5 \mathrm{mMol}$ & $0.84 \mathrm{a}$ & $5.10 \mathrm{a}$ & $43.00 \mathrm{a}$ & $3.67 \mathrm{a}$ \\
\hline & $1 \mathrm{mMol}$ & $0.82 \mathrm{a}$ & $4.47 \mathrm{a}$ & $40.00 \mathrm{a}$ & $1.33 \mathrm{a}$ \\
\hline & $2 \mathrm{mMol}$ & $0.93 a b$ & $4.16 \mathrm{a}$ & $42.33 \mathrm{a}$ & $5.33 \mathrm{a}$ \\
\hline Control & - & $1.63 \mathrm{~d}$ & $4.71 \mathrm{a}$ & $52.00 \mathrm{a}$ & $4.00 \mathrm{a}$ \\
\hline
\end{tabular}

Table 2. Effect of salicylic acid and benzoic acid on plant height, stem diameter, number of leaves, and chlorophyll

\begin{tabular}{|c|c|c|c|c|c|}
\hline Treatment & Concentration & $\begin{array}{l}\text { Plant height } \\
(\mathrm{cm})\end{array}$ & $\begin{array}{c}\text { Stem diameter } \\
(\mathrm{cm})\end{array}$ & Leaf number & $\begin{array}{l}\text { Chlorophyll } \\
\text { (SPAD Value) }\end{array}$ \\
\hline \multirow[t]{3}{*}{ Benzoic acid } & $0.5 \mathrm{mMol}$ & $53.40 \mathrm{a}$ & $1.89 \mathrm{a}$ & $11.27 \mathrm{a}$ & $40.41 \mathrm{a}$ \\
\hline & $1 \mathrm{mMol}$ & $51.00 \mathrm{a}$ & $1.77 \mathrm{a}$ & $10.48 \mathrm{a}$ & $38.13 \mathrm{~b}$ \\
\hline & $2 \mathrm{mMol}$ & $49.67 \mathrm{a}$ & $1.89 \mathrm{a}$ & $12.22 \mathrm{a}$ & $42.43 \mathrm{a}$ \\
\hline \multirow[t]{3}{*}{ Salicylic acid } & $0.5 \mathrm{mMol}$ & $50.77 \mathrm{a}$ & $1.76 \mathrm{a}$ & $11.62 \mathrm{a}$ & $41.56 \mathrm{a}$ \\
\hline & $1 \mathrm{mMol}$ & $52.17 \mathrm{a}$ & $1.87 \mathrm{a}$ & $11.45 \mathrm{a}$ & $39.21 \mathrm{ab}$ \\
\hline & $2 \mathrm{mMol}$ & $53.33 \mathrm{a}$ & $1.74 \mathrm{a}$ & $11.53 \mathrm{a}$ & $37.09 \mathrm{~b}$ \\
\hline Control & - & $55.83 \mathrm{a}$ & $1.82 \mathrm{a}$ & $10.68 \mathrm{a}$ & $37.87 \mathrm{~b}$ \\
\hline
\end{tabular}


respectively. In conclusion, our results indicated that exogenous SA and BA promoted stomatal closure in cocoa leaf by decreasing widthstomatal closure. Both hormones increased chlorophyll (SPAD value) at $0.5 \mathrm{mMol}$ of concentration. Salicylic and benzoic acid had no effect in plant height, stem diameter, number of leaf, length-stomatal apperture, number of stomata, and number of stelate trichome.

\section{ACKNOWLEDGEMENT}

We thank to Herwanto and Rais Widyanto helped compiling data for this research. Authors would like to thank the Ministry of Research, Technology, and Higher Education through Research Grant (INSINAS 2016).

\section{REFFERENCE}

Agrawal, A.A. (1999). Induced responses to herbivory in wild radish:effects on several herbivores and plant ûtness. Ecology, 80, 1713-1723.

Amborabé, B.E.; P. Fleurat-Lessard; J. Chollet \& G. Roblin. (2002). Antifungal effects of salicylic acid and other benzoic acid derivatives towards Eutypa lata: Structure-activity relationship. Plant Physiology \& Biochemistry, 40, 1051-1060.

Amin, A.A.; A. El-Kader; H.F. Abouziena; M. El-Awadi \& F.A.E. Gharib (2016). Effects of benzoic acid and thiourea on growth and productivity of wheat (Triticumaestivum L.) plants. International Scientific Researches Journal, 72, 132-149.

Bertoncelli, D.J.; R.C.D.S. Rocha; S.M. Mazaro; J.C. Possenti \& M.S.R. Borin (2015). Salicylic acid on the induction of resistance of tomato plants and control of Rhizoctonia solani Kuhn in vitro. Applied Research \& Agrotechnology, 8, 47-54.

Ditjenbun (2014). Analisis Perkembangan Serangan Penyakit VSD di Wilayah
Kerja BBPPTP Ambon. Laporan Triwulan Pertama 2014, Direktorat Jenderal Perkebunan, Kementerian Pertanian. Jakarta.

Ditjenbun (2014). Statistik Perkebunan Indonesia Kakao. Direktorat Jenderal Perkebunan, Kementerian Pertanian. Jakarta.

Fariduddin, Q; S. Hayat \& A. Ahmad (2003). Salicylic acid influences net photosynthetic rate, carboxylation efficiency, nitrate reductase activity and seed yield in Brassica Juncea. Photosynthetica, 41, 281-284.

Hanley, M.E.; B.B. Lamont; M.M. Fairbanks \& C.M. Rafferty (2007). Plant structural traits and their role in antiherbivore defense. Perspectives in Plant Ecology, Evolution and Systematics, 8, 157-178.

Harni, R.; W. Amaria \& Supriadi (2013). Keefektifan beberapa formulasi fungisida nabati eugenol dan sitronella terhadap Phytopthora palmivora Bult. asal kakao. Buletin RISTRI, 4, 11-18.

Kabiri, R.; F. Nasibi \& H. Farahbakhsh (2014). Effect of exogenous salicylic acid on some physiological parameters and alleviation of drought stress in Nigella sativa plant under hydroponic culture. Plant Protection Science, 50, 43-51.

Khandaker, L.; M. Akond; A.S.M.G. \& S. Oba (2011). Foliar application of salicylic acid improved the growth, yield and leaf's bioactive compounds in red amaranth (Amaranthustricolor L.). Vegetable Crop Research Bulletin, 74, 77-86.

Khokon, M.A.R.; M.A. Salam; F. Jammes; W. Ye; M.A. Hossain; E. Okuma,Y. Nakamura; I.C. Mori; J.M. Kwak \& Y. Murata (2017). MPK9 and MPK12 function in SAinduced stomatal closure in Arabidopsis thaliana. Bioscience, Biotechnology, and Biochemistry, 81, 1394-1400.

Kilaru, A.; B.A. Bailey; K.H. Hasenstein (2007). Moniliophthora perniciosa produces hormones and alters endogenous auxin and salicylic acid in infected cocoa leaves. FEMS Microbiology Letters, 274, 238-244. 
Kuvalekar, A.A. \& K.R. Gandhe (2010). Hydrogen peroxide generation and lignification by peroxidases from Acacia eburnea infected with Ravenelia esculenta. Plant Soil Environment, 56, 419-428.

Maity; A.J. Sharma; A. Sarkar; A.K. More; R.K. Pal; V.P. Nagane \& A. Maity (2017). Salicylic acid mediated multi-pronged strategy to combatbacterial blight disease (Xanthomonas axonopodis pv. punicae) in pomegranate. Europian Journal of Plant Pathology, 1-15.

Misra, N.; R. Misra; A. Mariam; K. Yusuf \& L. Yusuf (2014). Salicylic acid alters antioxidant and phenolics metabolism in Catharanthus roseus grown under salinity stress. African Journal of Traditional, Complementary and Alternative Medicines, 11, 118-125.

Nur'aini, F. (2015). Pengukuran intensitas penyakit VSD pada tanaman kakao. Warta, 27, 27-31.

Santoso, T.I.; M. Miftahudin; Y.C. Sulistyaningsih \& S. Wiyono (2017). Analysis of secondary metabolites as potential phytoalexins, their secretion sites and proposed resistance markers to vascular streak dieback in Theobroma cacao L. Pelita Perkebunan, $33,10-23$.

Senaratna, T.; D. Merritt; K. Dixon; E. Bunn; D. Touchell; K. Sivasithamparam (2003). Benzoic acid may act as the functional group in salicylic acid and derivatives in the induction of multiple stress tolerance in plants. Plant Growth Regulation, $39,77-81$.

Sukamto, S. \& Y.D. Junianto (1986). Evaluasi Perkembangan Penyakit VSD di Jawa. Balai Penelitian Perkebunan Jember, Jawa Timur.

Sukamto, S. (2008). Pengendalian penyakit. In: Wahyudi (Ed.) Buku Panduan Lengkap Kakao. Penebar Swadaya. Jakarta.

Sun, L.R.; F.S. Hao; B.S. Lu \& L.Y. Ma (2010). AtNOA1 modulates nitric oxide accumulation and stomatal closure induced by salicylic acid in Arabidopsis. Plant Signal Behavior, 5, 1022-1024.
Susilo, A.W.; P. Arisandy; I. Anita-Sari \& R. Harimurti (2016). Relationship analysis between leaf-stomata characteristics with cocoa resistance to vascular-streak dieback. Pelita Perkebunan, 32, 10 -21.

Traw, M.B. \& J.J. Bergelson (2003). Interactive effects of jasmonic acid, salicylic acid, and gibberellin on induction of trichomes in Arabidopsis. Plant Physiology, 133, 1367-1375.

Vance, C.P.; T.K. Kirk \& R.T. Sherwood (1980). Lignification as a mechanism of disease resistance. Annual Review of Phytopathology, 18, 259-288.

War, A.B.; B. Hussain \& H.C. Sharma (2013). Induced resistance in groundnut by jasmonic acid and salicylic acid through alteration of trichome density and oviposition by Helicoverpa armigera (Lepidoptera: Noctuidae). AoB Plants, $5,1-6$.

Williams, M.; T. Senaratna;K. Dixon; K. Sivasithamparam (2003). Benzoic acid induces tolerance to biotic stress caused by Phytophthora cinnamomi in Banksia attenuata. Plant Growth Regulation, 41, 89-91

Yao, H. \& S. Tian (2005). Effects of pre- and post-harvest application of salicylic acid or methyl jasmonate on inducing disease resistance of sweet cherry fruit in storage. Postharvest Biology and Technology, 35, 253-262.

Yuliasmara, F.; Sri-Sukamto \& A.A. Prawoto (2011). Induksi kekebalan sistemik untuk mencegah penyakit pembuluh kayu pada bibit kakao melalui aplikasi boron dan silikon. Pelita Perkebunan, 27, 204-215.

$$
* * 0 * *
$$

